\title{
Air Transport in Africa: Toward Sustainable Business Models for African Airlines
}

\author{
Stephan Heinz, John F. O’Connell*1 \\ Centre for Air Transport, Cranfield University, Martell House, Bedford, MK43 0TR, \\ $U K$
}

\begin{abstract}
:
Although there is a vast amount of literature on airline business models and their evolution in changing global landscapes, there is a general lack of research into the applicability of those models, traditionally defined in European and North American contexts, to the African scene. Implicit in this study is the hypothesis that the African environment is unique enough to warrant its own host of strategies, which may be distinctive enough to form part of a new strategic template, or business model. Initially, a review of existing literature is undertaken to profile the African aviation environment and evaluate existing airline business models and their evolution, both globally and in Africa. The methodology consists firstly of a cluster exercise, whereby 57 African airlines are analysed in terms of their network and size, to yield a number of heterogeneous groups which serve to identify the current business models of airlines on the continent. Following this, eight airlines (representative of the groups outlined in the cluster analysis) were subsequently selected for analysis in terms of the Product and Organisational Architecture framework. While it was evident that the traditional models are followed in Africa, in some instances variations were apparent. Full-service network carriers and regional carriers were concluded as being the most prominent and stable in the African market. The applicability of the low-cost carrier model in Africa was also examined at length, with mixed results. The analysis also raised network density and connectivity as essential components of business models for delivering profits in an African context.
\end{abstract}

\section{Introduction}

"The pursuit of sustainable profitability and competitive advantages has been changing different business models over the last decades." (Herszenhaut, 2010, p. 7) The operating environments in which airlines find themselves are far from homogeneous. The diversity of policies, geographies and economies across the world imply a need for a set of bespoke strategies, which can be represented in broad templates or business models designed to respond to the challenges presented by specific operating environments. This paper will aim to examine the most sustainable of such business models in the African context, by first identifying the current business models pursued by airlines on the continent, followed by a study of their sustainability from 2 key perspectives: market presence and product and organisational architecture (as used by Mason and Morrison, 2008).

\footnotetext{
* Corresponding author. Tel 00441234754247

E-Mail address: frankie.oconnell@cranfield.ac.uk
} 
Although there is a vast amount of literature on airline business models (Bieger et al, 2002; Tretheway, 2004; Graf, 2005, Gillen and Gados, 2008; DLR, 2008; Gillen and Gados, 2008; Jarach et al, 2009; Doganis, 2010) and their evolution in changing global landscapes, there is a general lack of research into the applicability of those models to the African environment. Implicit in this research is the hypothesis that the African environment is unique enough to warrant its own host of strategies, which may be distinctive enough to form part of a new strategic template or business model. In the context of African aviation, chief bodies of research centre on the impact of liberalisation on the continent (Chingosho, 2009; ICAO, 2003; Morisson, 2004; Schlumberger, 2010; United Nations Economic Commission for Africa, 2001), with limited reference to the evolution of airline strategies in response to these developments. Other salient research on African aviation has focussed on the challenges posed by the African operating environment (Abeyratne, 1998, Chingosho, 2009, Ssamula, 2009), but no explicit link is made to any recommendation on suitable strategies for African airlines to overcome such challenges. A whole range of problems persist in Africa that include: high costs; poor safety; government interference; corruption; low productivity and overstaffing; old aircraft; sparse demand over long sectors; low load factors; strong travel agent networks that operate in a cash economy; last minute booking profiles; low internet penetration; skills shortage; and difficulty in obtaining Air Operating Certificates (AOCs). These are all threats that need to be mitigated by African airlines if they are to remain economically sustainable, and will shape any conclusions on sustainable business models on the continent. Over the last decade, 37 airlines have launched in Africa and 37 have failed (Kamara, 2012) - the problems facing the aviation landscape within Africa are extensive.

\section{Commercial Aviation in Africa: A brief overview}

Africa accounts for just $2 \%$ of the world's air transport traffic in terms of passenger kilometres flown, despite this, the continent has the highest accident rate, with African carriers representing $23 \%$ of the western built jet hull losses in 2010 , which is a manifestation of the ongoing issues (IATA, 2010). This has contributed in forcing many passengers to switch to international carriers as Ethiopian Airlines CEO stated that $80 \%$ of the African traffic is flown by non-African carriers (Dunn, 2012), while in Nigeria the situation is considerably worse as $98 \%$ of its traffic is carried by nonAfrican carriers (Thomas, 2013). Research by O'Connell and Warnock-Smith (2012) revealed that Egyptair's overall share of international trips to/from Egypt just marginally increased from just $13.3 \%$ in 2007 to $15.7 \%$ by 2009 - many of the passengers were Egyptian residents, indicating the difficulty in attracting foreign passengers to travel with African based carriers. This scenario has compressed the output of the continent as AirportIS data computes that $80 \%$ of Africa's capacity is carried by just $20 \%$ of the domiciled carriers. The Yamoussoukro declaration - the blueprint for liberalising African airspace has been implemented within the continent's Regional Economic Communities (RECs), but to varying extents, thus leaving its continent-wide implementation fragmented and heterogeneous. There are 40 cities in Africa with populations of more than one million people and the Yamoussoukro agreement will likely be the catalyst for widespread connectivity, like that seen in the US and Europe after deregulation. The African environment presents a unique set of challenges that 
are unique to its environment that principally include high costs, poor aircraft utilisation and sparse demand.

African carriers face higher costs than their counterparts in other parts of the world. Fuel for example needs to be transported over long distances as a quarter of countries on the continent are land-locked - a problem exacerbated by poor infrastructure. The fleet size of most of the African carriers lack sufficient scale to negotiate favourable rates with fuel suppliers, while the practice of fuel hedging is not endorsed leaving African airlines exposed to volatile price fluctuations. Distribution is another constraint akin to Africa as low internet and credit card penetration rates force airlines to incentivise travel agents - Chingosho $(2009$, p. 32) states that commission payable to travel agents is typically about $7 \%$ of the ticket price. Furthermore, African service providers such as airports and navigational service providers are typically government-owned monopolies and consequently are all higher in Africa than the rest of the world - landing a 200 tonne aircraft for example in Johannesburg and Nairobi is around $\$ 2,500$ and $\$ 1,500$ respectively, while London Heathrow is considerably less at $\$ 500$ (IATA, 2010). African carriers have some of the oldest fleet in the world with $80 \%$ of all aircraft registering over an age of 10 years or older, this in-turn triggers higher associated maintenance costs, increased fuel consumption, poor reliability and increased downtime. Aircraft utilisation rates in Africa remains among the lowest in the world with rates averaging just 6.9 hours per day compared to Europe with 9.9 (Chingosho 2009) - this is attributable to poor scheduling, night flying restrictions, extended downtime of aging aircraft and a shortage of flight and maintenance personnel. African airlines also operate to the most destinations per aircraft when compared to other carriers across the globe. This is a reflection of poor aircraft usage with too many destinations being served by too few aircraft based on the need of state-owned airlines to be present in more markets than their fleet sizes can accommodate, often as a matter of 'market presence' coupled with national pride. Another focal challenge that African airlines must overcome is sparse demand, specifically on intra-African routes. This is a direct result of high airfares on the continent, which are a general symptom of the general lack of competition on intraAfrican routes as well as the inequality of income across the continent as air travel remains a luxury - even leisure travel is deemed inelastic (elasticity of 0.53 ) (Abrahams, 2002; Chingosho, 2009; Irandu, 2006; Schlumberger, 2010; Ssamula, 2008, 2009 and 2012). This sparse demand on African routes can be seen in the continent's low load factors at $69.7 \%$ in 2010 , which positions it at bottom of the world's league table, while the world's average rests at 75.2\% (IATA, 2010). Despite such challenges, the potential of the African aviation market has never been in doubt ${ }^{2}$, but the continent's carriers have so far struggled to tap this opportunity. Titus Naikuni, the current Kenya Airways CEO, summarises the potential for aviation in Africa succinctly, "Africa is the world's second largest continent with a population of 1 billion; this is comparable to China's and India's. Yet it is having difficulties communicating with itself - even by telephone. Roads are not good and railroads are not good, so you need air transport. The potential is big" (Buyck, 2010, p. 33). The

\footnotetext{
${ }^{2}$ Africa's natural resources will continue to attract extractive industries and the capital-intensive nature of these industries will ensure they remain high in the rankings of sectors drawing Foreign Direct Investment. African governments generated US\$415 billion in 2012 from taxes, licences and permit fees pertaining from oil and mining operations, up from $\$ 141$ billion in 2000 . This trend is set to grow exponentially into the future (Global Market Information Database, 2013). There are an estimated 127.7 billion barrels of oil in sub-Saharan Africa, an equivalent of approximately 9.6 per cent of the globe's total proven reserves (Gismatullin, 2011).
} 
development of a network suitable to the high costs and sparse demand in the African markets, will go a long way to developing an overall sustainable business model.

To understand the potential for growth of air transport in Africa, it is important to develop a picture of the continent's main economic and social characteristics. As alluded to earlier, the high concentration of air transport development in a few regions is a reflection of the continent's concentrated economies and populations in those regions, shown in Table 1.

Table 1: Concentrations of air transport, economies and populations within Africa

\begin{tabular}{|c|c|c|c|c|c|c|c|c|}
\hline \multicolumn{3}{|c|}{ Air Transport (Passenger Kilometres) } & \multicolumn{3}{|c|}{ Economy (GDP) } & \multicolumn{3}{|c|}{ Population } \\
\hline Country & $\begin{array}{c}\text { Contributio } \\
\mathbf{n}\end{array}$ & Cumulative & Country & Contribution & Cumulative & Country & Contribution & Cumulative \\
\hline $\begin{array}{l}\text { South } \\
\text { Africa }\end{array}$ & $27 \%$ & $27 \%$ & $\begin{array}{l}\text { South } \\
\text { Africa }\end{array}$ & $23 \%$ & $23 \%$ & Nigeria & $15 \%$ & $15 \%$ \\
\hline Egypt & $15 \%$ & $42 \%$ & Nigeria & $14 \%$ & $37 \%$ & Ethiopia & $8 \%$ & $23 \%$ \\
\hline Ethiopia & $10 \%$ & $52 \%$ & Algeria & $11 \%$ & $48 \%$ & Egypt & $8 \%$ & $31 \%$ \\
\hline Kenya & $8 \%$ & $60 \%$ & Morocco & $8 \%$ & $56 \%$ & $\begin{array}{l}\text { Congo, } \\
\text { DR }\end{array}$ & $7 \%$ & $38 \%$ \\
\hline Mauritius & $6 \%$ & $66 \%$ & Angola & $6 \%$ & $62 \%$ & $\begin{array}{l}\text { South } \\
\text { Africa }\end{array}$ & $5 \%$ & $43 \%$ \\
\hline \multicolumn{2}{|c|}{ Top 5} & $66 \%$ & & & $62 \%$ & & & $43 \%$ \\
\hline Algeria & $4 \%$ & $70 \%$ & Sudan & $5 \%$ & $67 \%$ & Tanzania & $4 \%$ & $47 \%$ \\
\hline Tunisia & $3 \%$ & $73 \%$ & Tunisia & $3 \%$ & $70 \%$ & Sudan & $4 \%$ & $51 \%$ \\
\hline Nigeria & $2 \%$ & $75 \%$ & Ethiopia & $3 \%$ & $73 \%$ & Kenya & $4 \%$ & $55 \%$ \\
\hline Namibia & $2 \%$ & $77 \%$ & Kenya & $3 \%$ & $76 \%$ & Algeria & $3 \%$ & $58 \%$ \\
\hline Seychelles & $1 \%$ & $78 \%$ & $\begin{array}{l}\text { Ivory } \\
\text { Coast }\end{array}$ & $2 \%$ & $78 \%$ & Uganda & $3 \%$ & $61 \%$ \\
\hline \multicolumn{2}{|c|}{ Top 10} & $78 \%$ & & & $78 \%$ & & & $61 \%$ \\
\hline
\end{tabular}

Source: Euromonitor, ICAO, IMF

In Africa, there is clearly a partial alignment between size of population, economy and air traffic. In general, countries with large populations and economies or small but rapidly growing populations and economies, represent an opportunity for the development of strong domestic (and/or international) networks (Chingosho, 2009).

\section{Methodology}

The methodology employed in this study, as summarised in Figure 1, adopts a reductive, step-wise approach. As the scope of the study reduces, the level of detail in 
the data increases. Initially, 57 African airlines (observed from a review of OAG data ${ }^{3}$ for all airlines in Africa) were examined, with relatively few data metrics, to identify the current business models pursued on the continent. Following this, and where data permits, a smaller sample of airlines is examined in terms of their Product and Organisational Architecture (POA), which, when combined with the analysis on the identified business models, yields conclusions on the most sustainable business model.

Figure 1: Overview of methodology
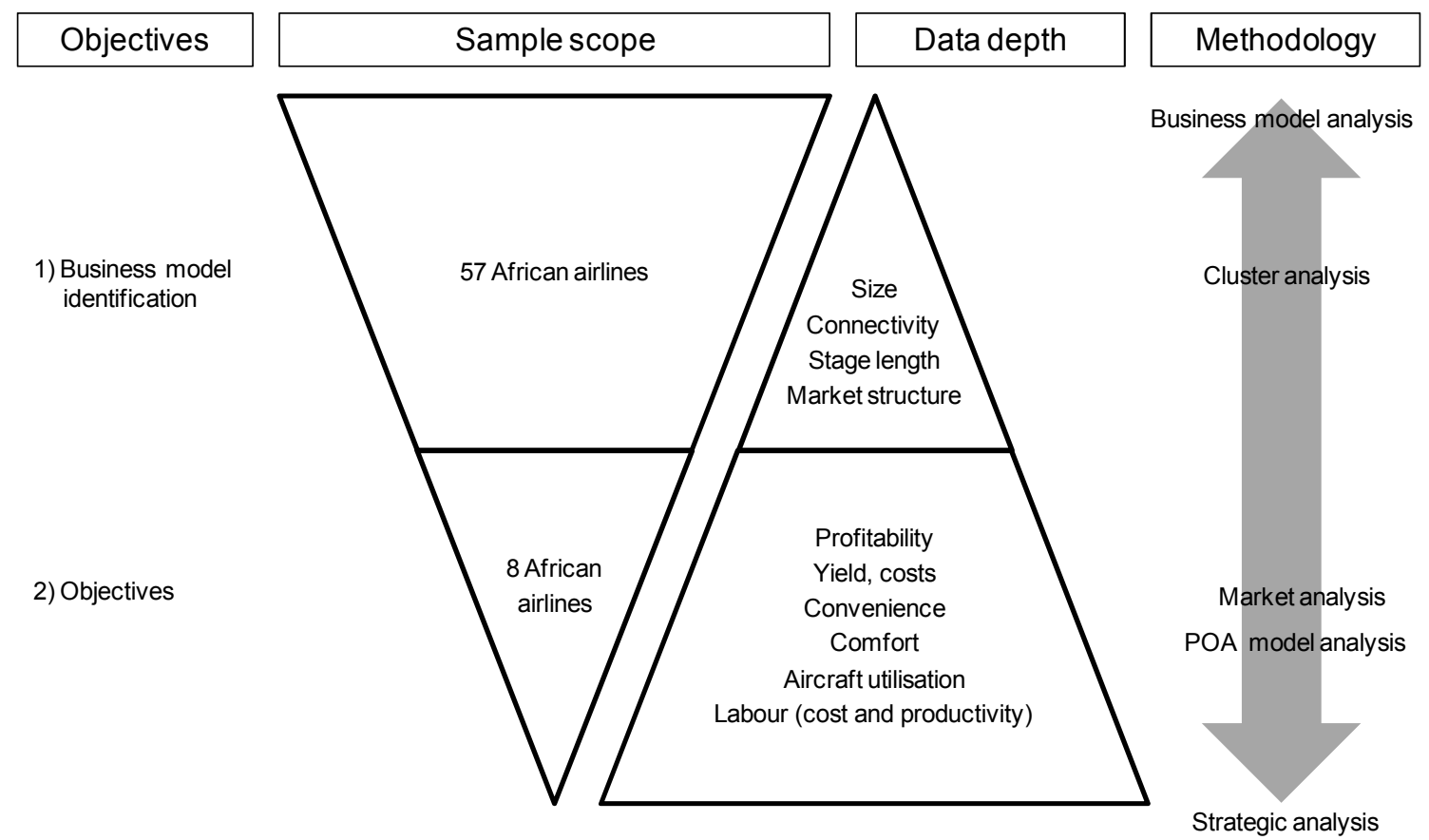

Research by Mason and Morrison (2008) used the Product and Organisational Architecture (POA) to provide a meaningful platform on which to base a comparative analysis of airline business models. The POA methodology is an ideal tool for evaluating how an airline's business model components interplay to deliver profits and therefore remain sustainable. In addition to this, the POA framework can also be used to identify and classify business models, given that an airline's model can be defined by the emphasis it places on various model components in delivering profits. POA framework as proposed by Mason and Morrison is detailed in Figure 2.

\footnotetext{
OAG holds historical flight details for more than 1,000 airlines and over 4,000 airports. The aggregated data feeds the world's global distribution systems and travel portals, and drives the internal systems of many airlines, air traffic control systems, aircraft manufacturers, airport planners and government agencies around the world.
} 
Figure 2: Product and Organisational Architecture (POA) framework

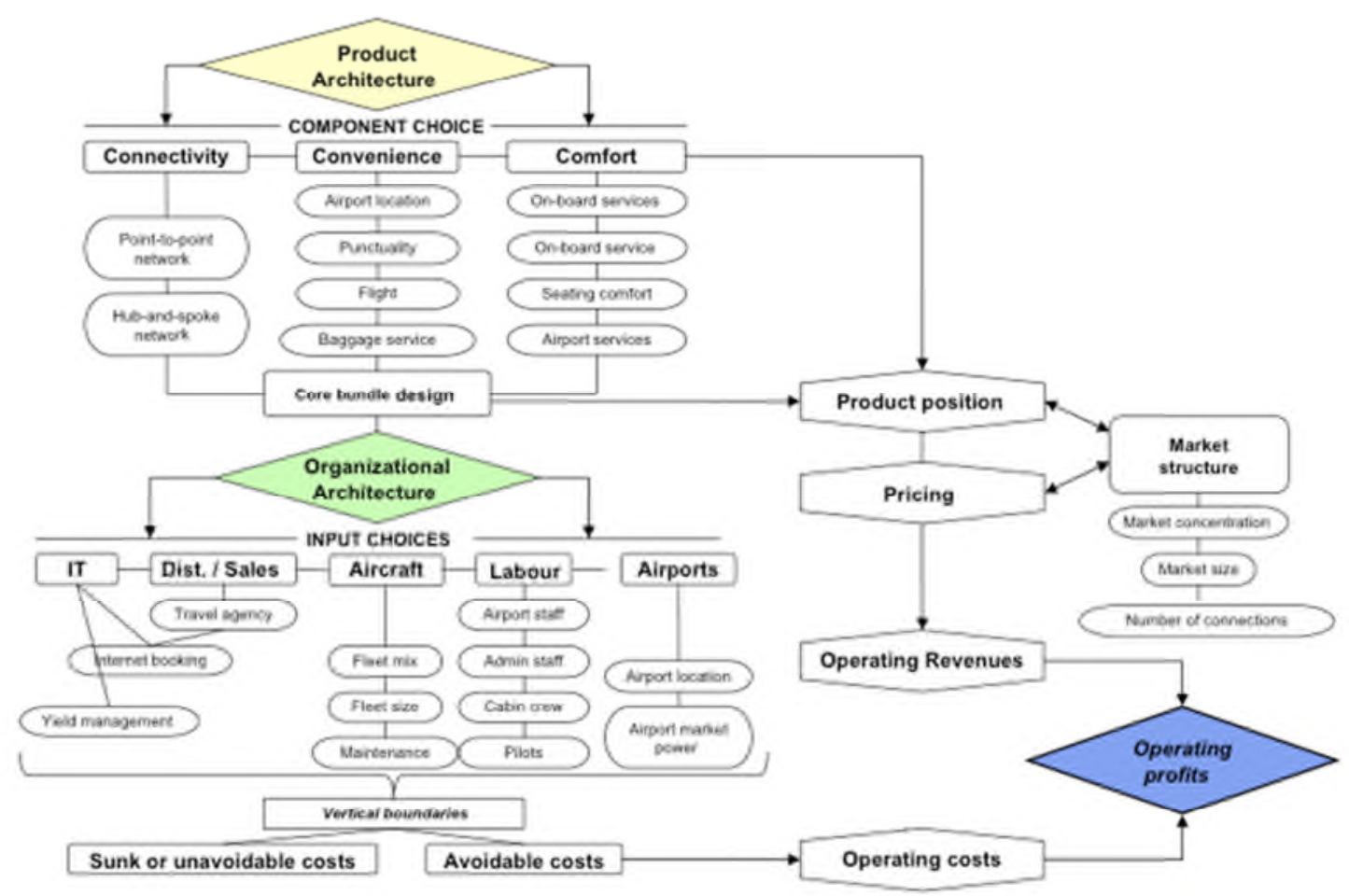

Source: Mason and Morrison (2008)

Theoretically, including all 57 airlines in the initial POA sample would deliver a more comprehensive understanding of African airline business models. Owing to the lack of sufficient data covering all African airlines, using all POA metrics is not feasible. Nevertheless, in recognising that some model components are more integral in defining an airline's business model than others, a continent-wide classification of business models becomes possible by applying only those integral model components to the original sample of 57 African airlines. There is consensus in the existing literature that an airline's route network forms a fundamental component of its business model (Tretheway, 2004; Gillen, 2006; Niehaus et al, 2009; Fageda and Flores-Fillol, 2012; among others). To this end, two of the four key variables selected to identify business models reflected network structure, including connectivity and average stage length. Regarding the former, for instance, Doganis (2012) states that connectivity is perhaps the most important core element that can distinguish between different airline business models, as it implies a choice of network design that distinguishes hub-and-spoke (airline-supplied connectivity) from point-to-point (passenger-supplied) networks. Alliance and code share partners have not been included in the study.

The third and fourth variables included were Available Seat Kilometres (ASKs) as a measure of airline size, and the Herfindahl-Hirschman Index (HHI). The latter 
provides a measure of the competitiveness of the markets in which the sample carriers operate. The markets considered are direct routes only and not O\&D pairs, which would require consideration of airport connecting times and network circuity. Nevertheless, the HHI metric delivers an insight into what extent carriers may operate in monopolistic environments and provides a platform for understanding government involvement and the resulting impact on the business models studied. All data collected were for the year 2010. Table 2 defines the key variables chosen and the relevant sources of data.

Table 2: Summary of preliminary cluster analysis variables

\begin{tabular}{|c|c|c|c|c|}
\hline \multicolumn{3}{|c|}{ VARIABLES } & SOURCE & DESCRIPTION \\
\hline 1 & $\begin{array}{c}\text { Average } \\
\text { Connectivity }\end{array}$ & & OAG & $\begin{array}{l}\text { Average number of flights* departing between } 1 \\
\text { and } 3 \text { hours of each arriving flight at airline's } \\
\text { home base }^{1}\end{array}$ \\
\hline 2 & $\begin{array}{l}\text { Average } \\
\text { Weighted Stage } \\
\text { Length }\end{array}$ & $\begin{array}{c}\text { Network } \\
\text { Structure }\end{array}$ & AirportIS & $\begin{array}{l}\text { Equation 1: Average weighted stage } \\
\text { length } \\
\text { Adjusted stage length }=\frac{\sum_{i=1}^{n} d_{i} S_{i} f_{i}}{\sum_{i=1}^{n} S_{i} f_{i}} \\
s_{i}=\text { route } i \text { 's seats, } f_{i}=\text { route } i \text { 's frequency } \\
n=\text { number of routes } \\
\text { Source: Lufthansa Consulting }\end{array}$ \\
\hline 3 & ASK & Size & AirportIS & Available Seat Kilometres \\
\hline 4 & HHI & $\begin{array}{c}\text { Market } \\
\text { Structure }\end{array}$ & $\mathrm{OAG}$ & $\begin{array}{l}\text { Equation 2: Calculation of HHI } \\
\qquad \mathrm{HHI}=\sum_{\mathrm{i}=1}^{\mathrm{N}} \mathrm{S}_{\mathrm{i}}{ }^{2} \\
s_{i}=\text { firm } i \text { 's market share, } N=\text { number of firms }\end{array}$ \\
\hline
\end{tabular}

Note: Stage length $=$ Route distance flown. In this case the stage length (distance) has been weighted using frequency and seats for each flight over the year for that airline. This reflects an emphasis that a particular route network has on longer or shorter range routes.

After the initial business model classification exercise involving 57 African carriers, a representative carrier from 5 of the 7 resulting classifications was taken forward into the POA analysis stage. This stage required a deeper level of financial and operational data, the availability of which is limited among African carriers, hence not all 7 model classification were analysed but rather only those which were most definitive and included wider sources of data. As consistent delivery of profits drives sustainability, the model classifications which perform best in those components driving profitability can be seen as sustainable in the African environment. 
The POA methodology adopted uses benchmark metrics to functionalise the POA concept. According to Mason and Morrison (2008, p. 77), "by developing separate indices for different elements in the business model $^{4}$, the interaction between the items and the importance of each item to the overall performance of each airline can be more easily identified and their impact on the overall performance assessed." The POA model therefore consists of a series of indices, each of which contains a number of benchmark items. As this research is not focused on any particular model, the indices were adjusted accordingly to reflect its African operating environment. The index of "airport attractiveness" was removed, considering that the role of secondary airports and low cost terminals on the continent is almost non-existent. Although the distribution index may have been relevant in determining various African airlines' levels of internet sales, the lack of reliable data in this area meant that this index was excluded. Other notable adaptations to the model include the replacement of the connectivity benchmark item "all destinations available at airport served" with the "average number of flights departing after each arriving flight at the airline's hub"(as shown in Table 2). This research also encapsulates both short and long haul stage lengths - it takes over eight hours to fly the 3,800 mile distance from Johannesburg to Cairo. As a result, the revenue items which may be influenced strongly by the length of haul, such as fare and revenue per sector, were omitted and instead, the revenue index was simplified to represent a simple measure of yield (Revenue per Passenger Kilometre). Table 3 summarises the indices included, as well as the relevant benchmark item, data source and a brief description and justification of each item's inclusion. All data are for the year 2010 and, in some instances, the financial year 2009/2010.

\footnotetext{
${ }^{4}$ These authors only applied the indices on comparing low-cost business models which have little to no connectivity and operate on short haul sectors, which significantly limited its value. This research extrapolates the core platform of the POA analysis to include many other types of airline business models such as full service, regional and charters pertaining to Africa.
} 
Table 3: Summary of indices and benchmark items

\begin{tabular}{|c|c|c|c|}
\hline INDEX & $\begin{array}{c}\text { BENCHMARK } \\
\text { ITEM }\end{array}$ & $\begin{array}{c}\text { DATA } \\
\text { SOURCE }\end{array}$ & DESCRIPTION \\
\hline Profitability & Operating margin $(\%)$ & \multirow{3}{*}{ Annual Report* } & Identifies overall success of airline business \\
\hline Cost & Cost per ASK (\$ cents) & & Summarises airlines' cost position \\
\hline Revenue & Revenue per RPK (\$ cents) & & Summarises airlines' revenue position \\
\hline \multirow{3}{*}{ Connectivity } & Departures per airport per day & AirportIS & \multirow[t]{2}{*}{ Measure of network density } \\
\hline & Routes offered & AirportIS & \\
\hline & Connectivity & OAG & $\begin{array}{l}\text { Average number of departures between } 1 \text { and } 3 \\
\text { hours after each arriving flight at main base. }\end{array}$ \\
\hline \multirow{3}{*}{ Convenience } & $\begin{array}{l}\text { Average weekly frequency per } \\
\text { route }\end{array}$ & AirportIS & $\begin{array}{l}\text { Measure of convenience, often an area where } \\
\text { African airlines perform poorly }\end{array}$ \\
\hline & Punctuality (\%) & Flightstats & On time departure within 15 minutes of scheduled \\
\hline & Baggage Services (\%) & Air Valid* & \multirow[t]{2}{*}{ As rated by customers } \\
\hline \multirow{3}{*}{ Comfort } & Average seat rating $(\%)$ & Air Valid* & \\
\hline & Economy seat width (inches) & Seatguru* & \multirow[t]{2}{*}{ Measure of on-board product comfort } \\
\hline & Economy pitch (inches) & Seatguru* & \\
\hline \multirow{3}{*}{ Aircraft } & Utilisation (hrs per day) & ASCEND* & \multirow{2}{*}{$\begin{array}{l}\text { Measure of fleet productivity but also highlights } \\
\text { airlines with longer sectors lengths }\end{array}$} \\
\hline & Aircraft sectors per day & ASCEND* & \\
\hline & $\begin{array}{c}\text { Most populous aircraft in fleet } \\
(\%)\end{array}$ & $\begin{array}{l}\text { Flight Global } \\
\text { Database }\end{array}$ & Implications for maintenance costs \\
\hline \multirow{3}{*}{ Labour } & Passengers per employee & $\begin{array}{c}\text { Flight Global } \\
\text { Database/Annual } \\
\text { Report* }\end{array}$ & \multirow[t]{3}{*}{$\begin{array}{l}\text { Measure of employee productivity, typically an area } \\
\text { in which African airlines perform poorly. }\end{array}$} \\
\hline & Employees per aircraft & Annual Report* & \\
\hline & ASK per employee ('000) & $\begin{array}{c}\text { Flight Global } \\
\text { database /Annual } \\
\text { Report* }\end{array}$ & \\
\hline \multirow{4}{*}{$\begin{array}{l}\text { Market } \\
\text { Structure }\end{array}$} & Median HHI (seats) & AirportIS & \multirow{4}{*}{$\begin{array}{l}\text { Measure of competitiveness of the market in which } \\
\text { each airline operates. The HHI ranges from } 0 \text { - } \\
10000 \text { with } 10000 \text { being perfect monopoly } \\
\text { (see Table 2) }\end{array}$} \\
\hline & Average HHI (seats) & AirportIS & \\
\hline & Average competitors per route & AirportIS & \\
\hline & $\begin{array}{c}\text { Average capacity share of seats } \\
(\%)\end{array}$ & AirportIS & \\
\hline
\end{tabular}

Note: *For Camair-co data used from airline business plan or estimated based on similar airline/aircraft type (in the case of comfort for example)

\subsection{Benchmark item and overall index calculation}

The relevant benchmark items for each airline were calculated based on a "best in class" performance, whereby each airline was scored in relation to the best in class airline for that particular item, in line with the methodology proposed by Mason and Morrison (2008), two variations of calculation were employed, depending on whether or not the best in class for that item was the lowest or highest value. Once each 
benchmark item was calculated, the results were combined to compute the overall index, weighting each benchmark item to reflect the fact that some items in the index were more significant than others in their contribution. Consistent with the methodology, weights were based on a correlation of each benchmark item with profitability.

The final index score is then calculated, by placing each airline in relation to the best performer in each benchmark area (profit, cost, labour, etc) and presenting the results on a series of radar plots for both 2007 and 2010. Further, each index score is correlated with profitability, to gain an understanding of which areas of the business models of the airlines under analysis drive profitability. Carriers that perform best in these areas, are considered to employ sustainable business models, given that continuity and economic sustainability are driven by profit and continuous returns. Index scores were also correlated with each other, to gain an understanding of how they interrelate, highlighting a number of meaningful relationships. These results were presented in the form of a correlation matrix and scatter plot.

\section{Results and analysis}

\subsection{Identified business models employed by African carriers}

The initial cluster analysis based on the four variables presented in Table 2 identified seven separate classifications of business model. To present these results, a multivariate graphical cluster was developed using a bubble chart. Connectivity is shown on the y-axis, average adjusted stage length on the x-axis, Available Seat Kilometers (ASKs) in bubble size and the HHI index in bubble colour (Figure 3). The groupings were named as follows: Full-Service Network Carriers (FSNC), Established Regional Carriers (ERC), Long-Haul Niche Carriers (LHNC), True LowCost Carriers (TLCC), Emerging Regional/Low-Cost Carriers (ERLCC), Emerging Full-Service Network Carriers (EFSNC) and Small Full-Service Carriers (SFSC). 


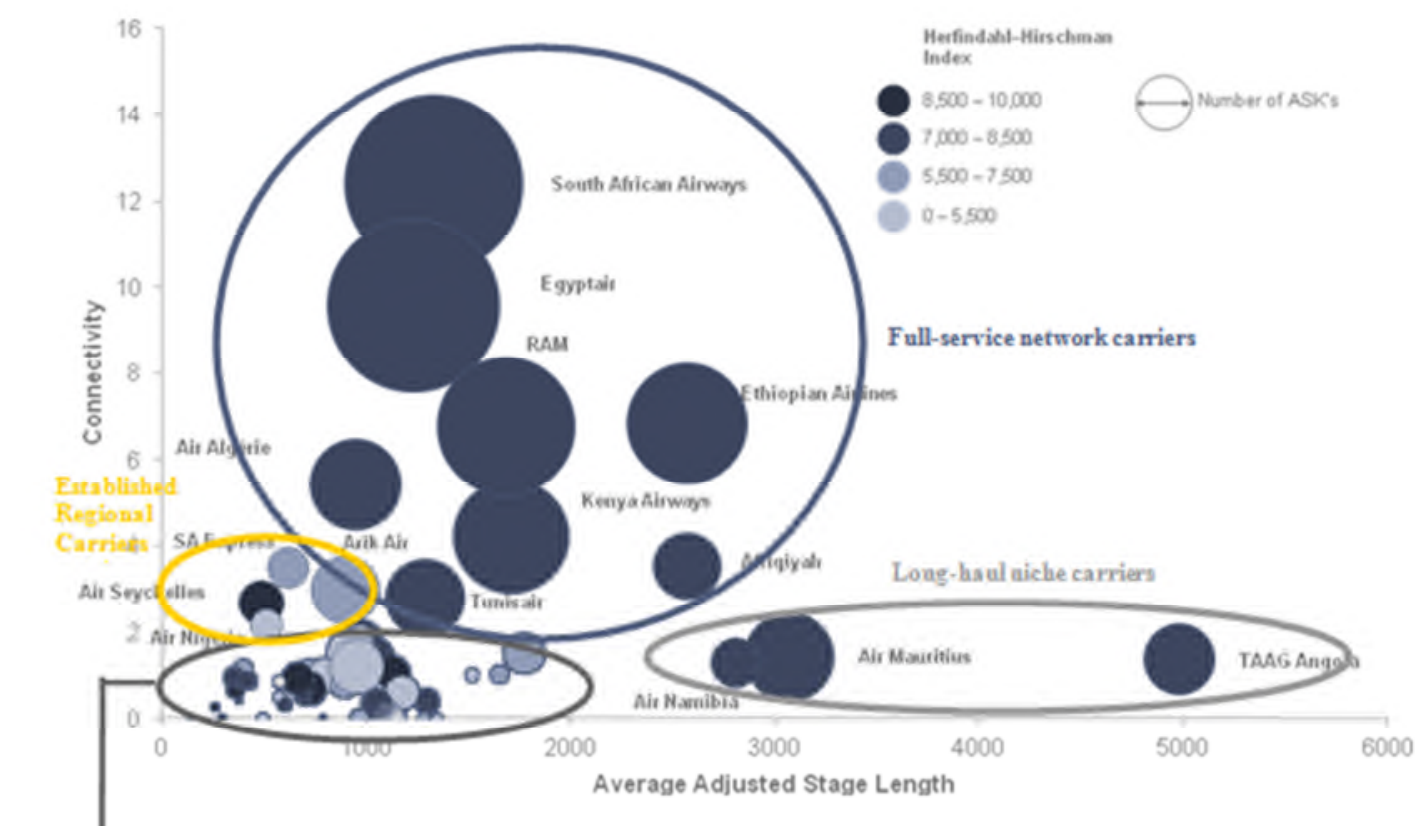

Figure 3: A Cluster Analysis of Africa's Airlines

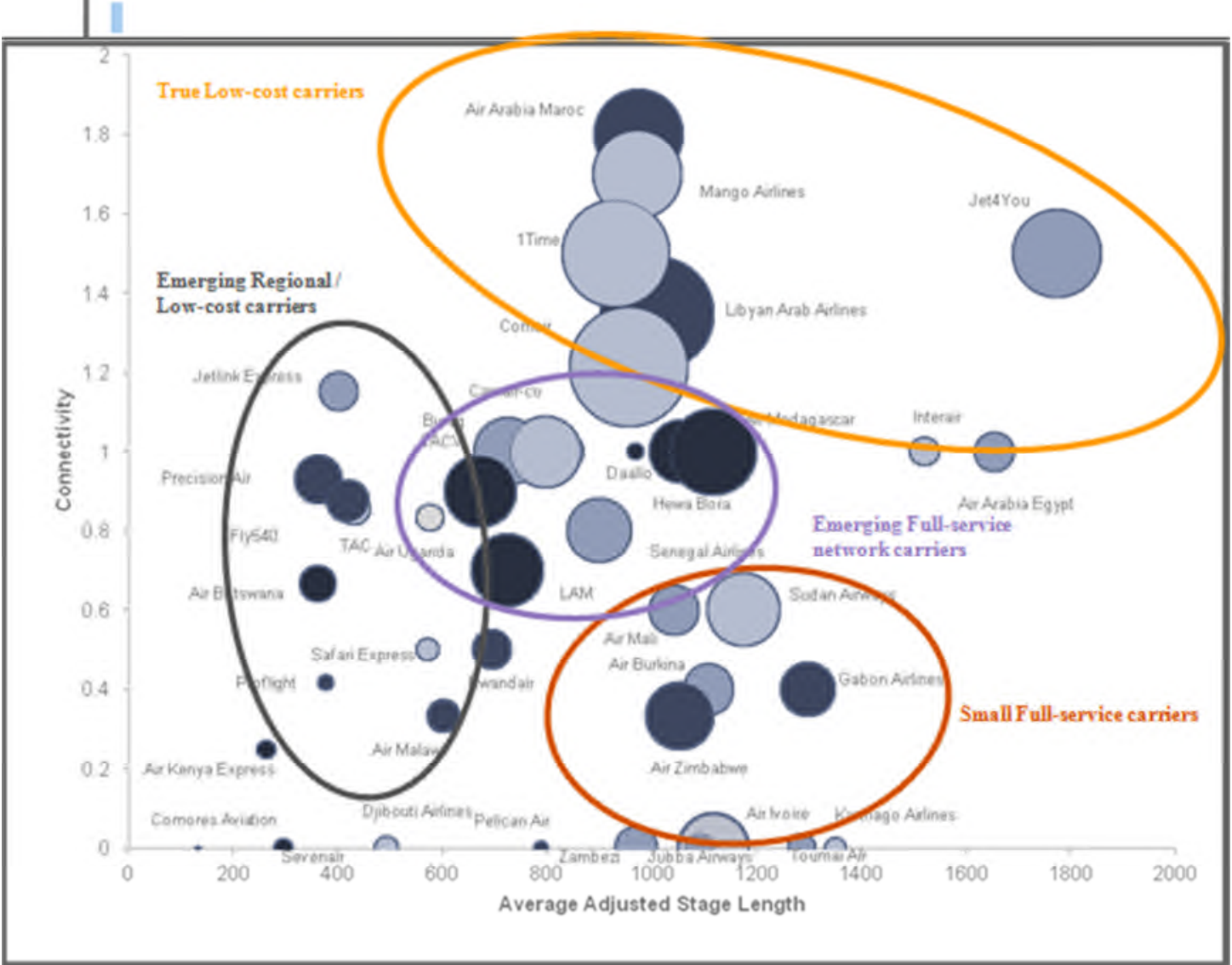

Full-service Network Carriers (FSNC)

Referring to Figure 3, it is clear that Africa is composed of a small number of dominant carriers including South African Airways, Egyptair, Kenya Airways, Ethiopian Airlines, Royal Air Maroc and Air Algérie - these all practice the 
characteristics that embellish the business model of full service carriers such as serving long haul and short haul routes, connectivity within a hub and spoke operation, multiple code sharing partners, 2 class configuration, serving primary airports, etc. By virtue of their high connectivity values ranging from around 4 to 13 , with slightly higher than average stage lengths, these carriers constitute Africa's FSNCs. They also have relatively high HHI values, often driven up by governmentsupported monopolies within domestic networks.

\section{Established Regional Carriers (ERC)}

These carriers include South African Express, Arik Air, Air Nigeria, Air Seychelles, Tunisair and Afriqiyah. The services offered by regional carriers can be summarised in three forms; feeder services, own hub and spoke services or point-to-point niche services. Overall, however, the regional carrier route networks are geographically confined. In this sense, South African Express and Air Nigeria are perhaps the two most obvious regional carriers. The relatively low HHIs for both airlines suggest, however, that rather than relying on niche monopoly markets, they act as either regional hub-carriers and/or regional feeders, as is the case with South African Express. It is also evident that Africa consists of a number of carriers which may appear to be regional models but, as a result of a minimal long-haul service, cannot be accurately classified as regional carriers.

\section{Long-Haul Niche Carriers (LHNC)}

These carriers rely heavily on long-haul point-to-point traffic from their home airports. Niche point-to-point demand from strong tourist, VFR (visiting friends and relatives) or business traffic is fundamental to these carriers' sustainability and is reflected in the generally low connectivity values. Air Mauritius demonstrates all of these characteristics as eight out of a total of twelve aircraft are long range derivatives that mostly target high yielding European holiday makers who all disembark at Mauritius' Sir Seewoosagur Ramgoolam International Airport - consequently the carrier does not practice hub and spoke operations as transfer traffic is not an intrinsic part of its core competencies.

\section{True Low-Cost Carriers (TLCC)}

Among the large group of smaller carriers with connectivity values below two, there is an obvious group including airlines such as Air Arabia Maroc, Mango Airlines, Comair (including low-cost carrier Kulula), 1Time and Libyan Arab Airlines. With the exception of the latter, these represent a selection of Africa's low-cost airlines. It should be stressed that the higher connectivity values of between one and two, is not representative of a hub and spoke strategy facilitating connectivity, but more likely a byproduct of the airlines' larger size and higher frequencies overall. A further observation is that these carriers reflect relatively low HHIs, consistent with the idea that true low-cost airlines in Africa can be found in regions with high demand and more competition, as opposed to less competitive, more sparse niche markets.

\section{The Emerging Regional/Low-cost carriers (ERLCC)}

Among the smaller carriers in Africa, there appears to be a group with lower stage lengths and connectivity values of around one. In general, these are privatised airlines, and this, combined with the overall short stage lengths and small size, indicates that these carriers could be classified as privatised, emerging regional and low-cost 
carriers. The small size of these carriers means that, rather than being a byproduct of high frequencies, the connectivity is created by clever scheduling, albeit resulting in only one connection on average. These airlines also have relatively high HHI values which, in some cases, may represent operations in monopolistic niche markets, in line with the regional carrier model. Although some carriers in this group may claim to be low-cost carriers, such as Fly540, they are more representative of regional models or at least regional/low-cost hybrids.

\section{Emerging Full-Service Network Carriers (EFSNC)}

As with the emerging regional/low-cost carriers, the connectivity reflected among these carriers is likely to have been created through the setup of the timetable, as the small size of these carriers' means that, unlike the larger point-to-point carriers, connectivity as a by-product of size and frequency is less likely. What is a salient characteristic of this model, however, is the longer stage length which, in some instances, is reflective of a long-haul operation (Camair-co, LAM, and Senegal Airlines). Nevertheless, carriers such as Air Malawi, Rwandair Express and Air Uganda are more suited as ERCs, given that they lack any long-haul operations. It is clear that the boundary between these carriers and ERCs is somewhat blurred, and only maintained based on the contention that ERCs employ a geographically confined route network lacking any long-haul operations.

\section{Small Full-Service Carriers (SFSC)}

A final business model consists of small, predominantly state-owned carriers with longer stage lengths but low connectivity, which could be representative of niche markets being targeted. This is contradicted, however, by relatively low HHI values, with the exception of Air Zimbabwe and Gabon Airlines, both of which operate a long-haul service. Despite an obviously larger size than the ERLCC with average connectivity of around one, these carriers seem to lack any level of connectivity. This may be representative of fragmented and poorly planned schedules and route networks, as well as small fleets, synonymous with weak state-owned African airlines. These airlines are likely to struggle with sparse demand on above average stage lengths, and seem to rely on point-to-point traffic despite operating in what appears to be more competitive markets

\subsection{Product and Organisational Architecture (POA) analysis}

\subsubsection{Yield, load factor or combination strategy}

Figure 4 demonstrates the relationship between load factors and yields for the various business models discussed in Section 4.1. Small full-service carriers, emerging fullservice carriers and long-haul niche carriers remain in a vulnerable position, in line with some of the earlier discussion. The regional carriers' reliance on high yields and the charter carriers' reliance on high load factors are also apparent. The emerging low-cost/regional carriers seem to be more aligned with the regional carrier than the true low-cost carrier, as suggested in the earlier discussion of Fly540. Despite claims of being low-cost carriers, these airlines display higher yields and lower load factors than the true low-cost model carriers. Unexpectedly, the full-service network carriers show lower yields but higher load factors as is the case with the true low-cost carriers. This is due to the fact that, even in competitive environments and areas of strong 
demand where true low-cost carriers in Africa operate, yields are perhaps higher than traditional low-cost carriers in other regions of the world. While the emerging regional/low-cost carriers seem to be in the vicinity of the regional carriers, the emerging full-service network carriers are in the vicinity of the full-service network carriers, validating the link between these models and their more mature variations.

Figure 4: Yield vs. Load Factor by business model (based on average yield and load factors 2005-2010)

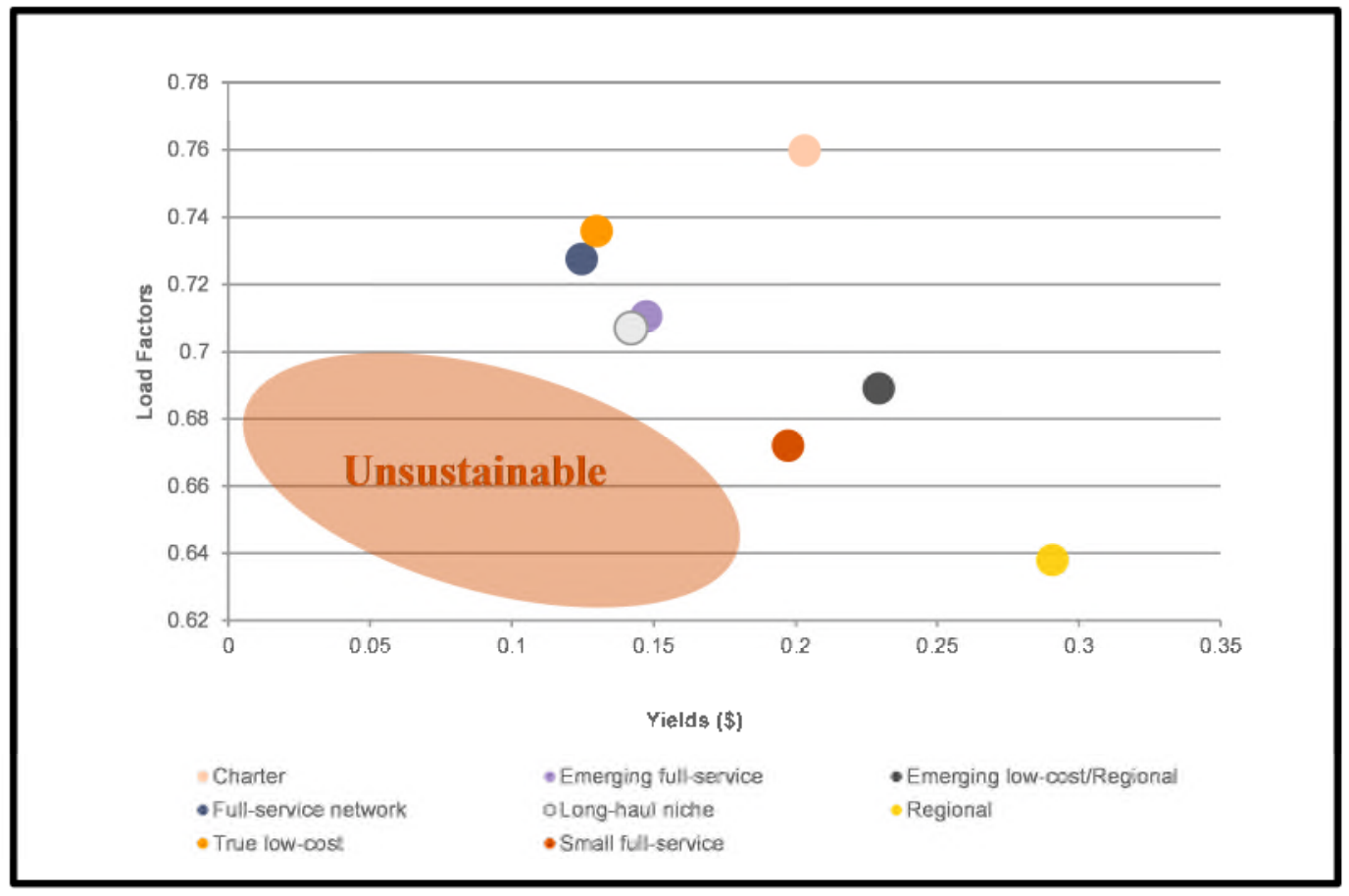

It is obvious that while some models are based on high load factors and lower yields, for others the inverse is true. Therefore, by looking at African markets in terms of demand (Figure 5), an understanding of which models may be suited to which regions can be developed. This recognises that African markets are not homogeneous and that different business models may be sustainable in different regions. For example, in Northern and Southern Africa where demand is strongest, the low-cost carrier model is likely to be suitable. In West Africa, where demand continues to be thin and yields high, it is the regional carrier model which is likely to dominate. The long distances and thin demand of inter-regional markets mean that the full-service network carriers, which can bundle sparse demand through a hub, thereby overcoming low load factors, are best suited. 
Figure 5: Bi-directional passengers for top 300 intra-Africa O\&D pairs (based on 2010 demand)

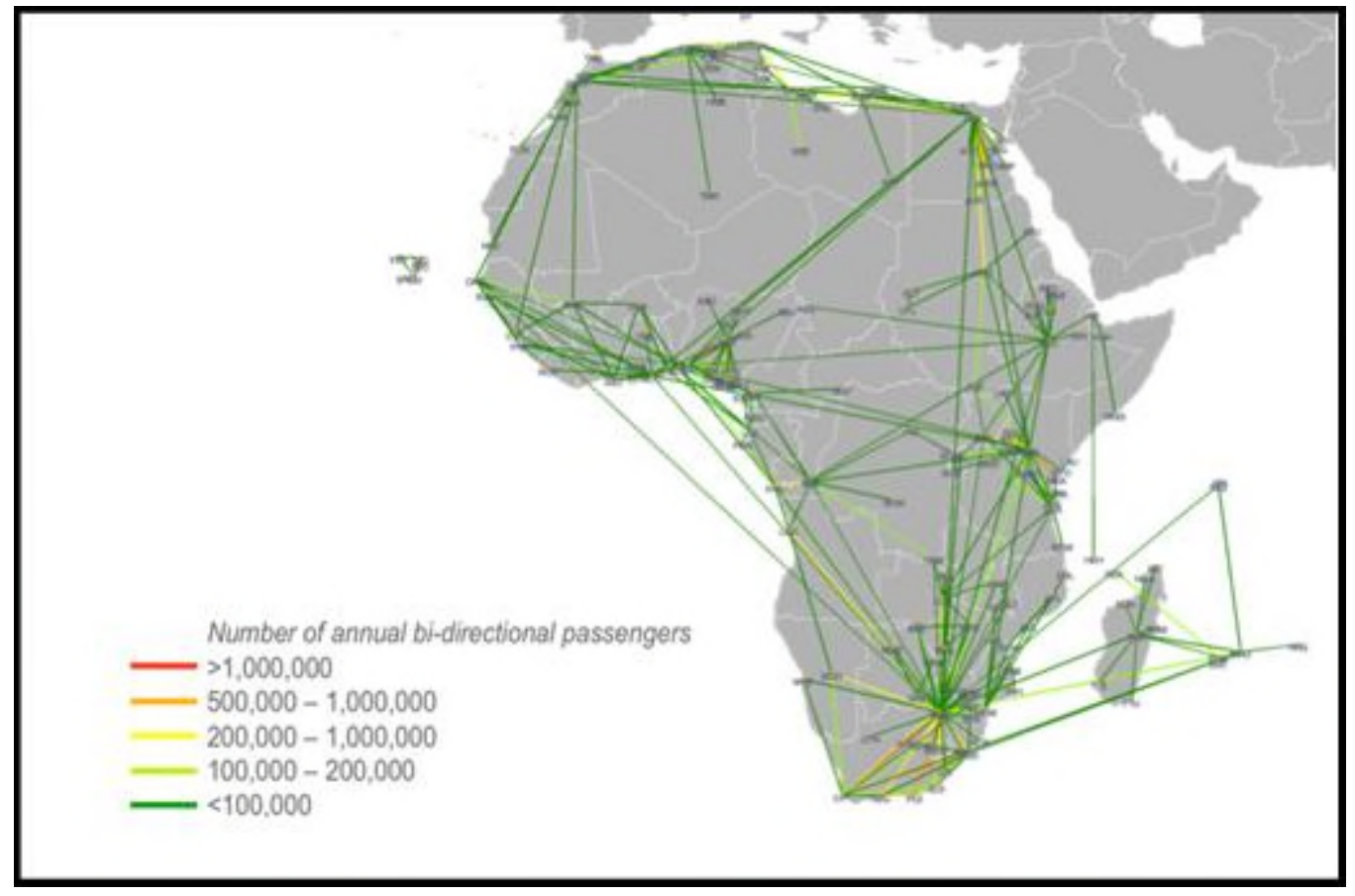

\subsubsection{Business model radar plots}

South African Airways, Ethiopian Airlines, Kenya Airways and Egyptair, chosen as the FSNCs, all show a strong alignment of their key model components (Figure 6). Kenya Airways and Ethiopian Airlines in particular display very similar models. The main discrepancies can be found in the cost and revenue indices. Where airlines are strong cost performers, they are weak revenue performers, so cost and revenue leadership appear, at first glance, to be mutually exclusive. As expected, most carriers display connectivity values higher than average, with the exception of Kenya Airways, which is an allusion to these carriers' well established hub and spoke networks. Data from PaxIS revealed that Ethiopian Airlines transferred around 296,000 passengers in 2012 from all of Africa to Europe through its hub at Addis Ababa, up from 102,000 in 2006. However these Network carriers are being severely threatened by Gulf based carriers that are continuously strengthening their footprint in Africa. Emirates for example operated 142 flights per week in 2011, up from just 56 in 2004 - it transported 1.25 million passengers from Africa to all of Asia through its Dubai hub in 2012, which was three times more than it carried some six years earlier. 
Figure 6: Full Service Network Carriers (FSNC) results based on POA analysis

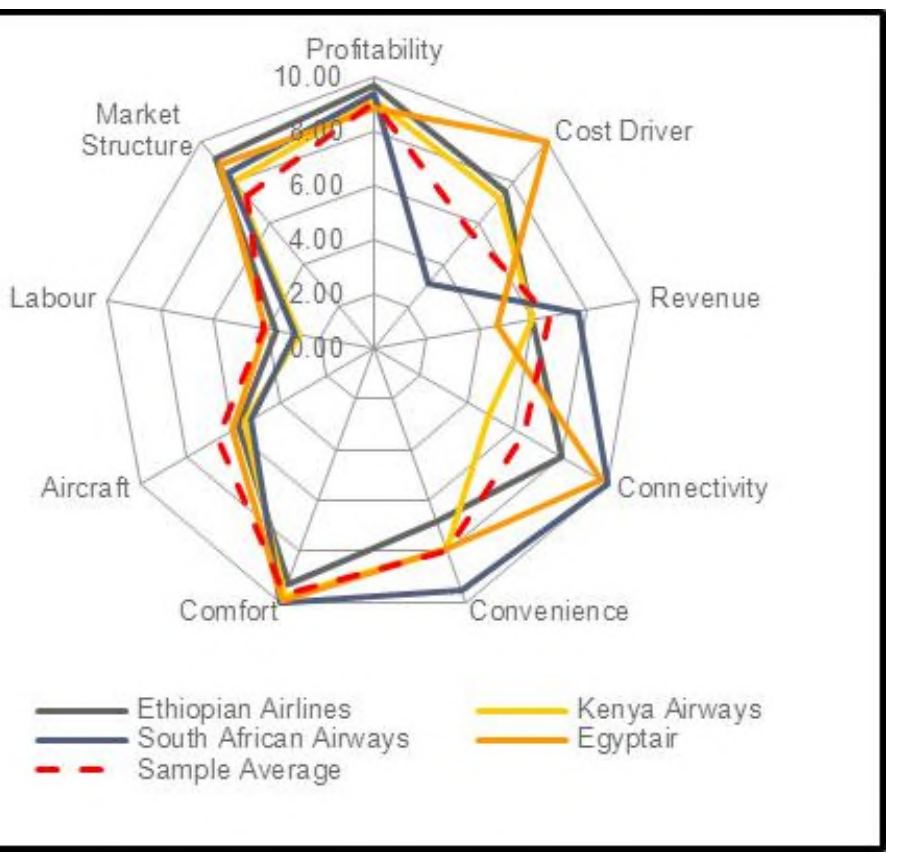

For the selected ERCs (Figure 7), there is a clear alignment between the business model of SAExpress 2010 and UK regional carrier FlyBe 2006 (the latter was taken from M\&M's 2008 study). There is an obvious emphasis on revenue leadership, although a clear difference between the two models is connectivity. While FlyBe is a point-to-point niche market regional carrier, SAExpress is a feeder, concentrating its operations at the hubs of South African Airways. The relatively highly concentrated market structures for the regional model may be indicative of the niche markets each carrier serves with few operators.

Figure 7: Established Regional Carriers (ERC) results based on POA analysis

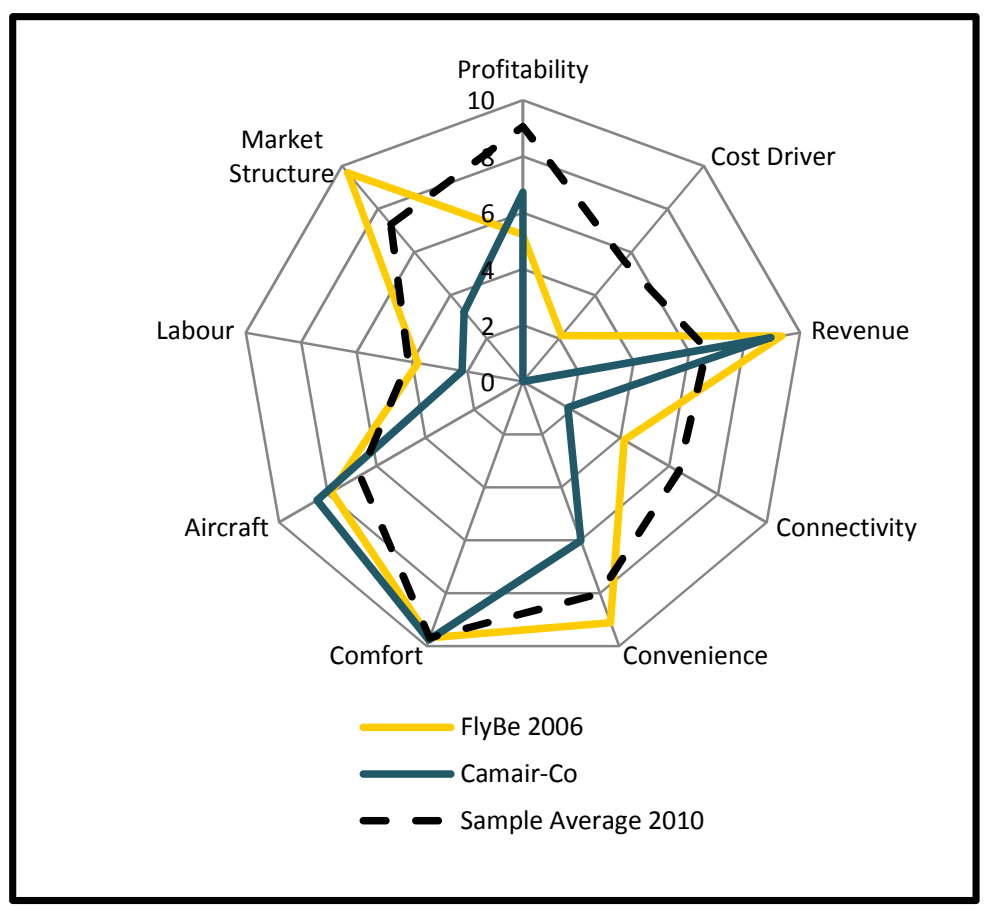


As discussed, the EFSNC is only differentiated from the regional carrier by virtue of the presence of long-haul operations (in most cases). This is evident in the selected carrier's business model (Figure 8), which seems to be based on a strategy of revenue rather than cost leadership, and is aligned with the typical regional model (shown again by FlyBe) in most indices. Cameroon's Camair-co (used as a proxy for this carrier type) does, however, show a lower market concentration (market structure) than FlyBe, indicating that the carrier operates in a more competitive market, rather than in monopolistic niche markets. OAG data for 2012 shows that Camair $^{5}$ has around $11 \%$ of the seat capacity between Cameroon and the rest of Africa, while Air France (operating between Malabo, Equatorial Guinea to Douala, Cameroon) has 12\% as does Royal Air Maroc.

Figure 8: Emerging Full Service Network Carriers (EFSNC) results based on POA analysis

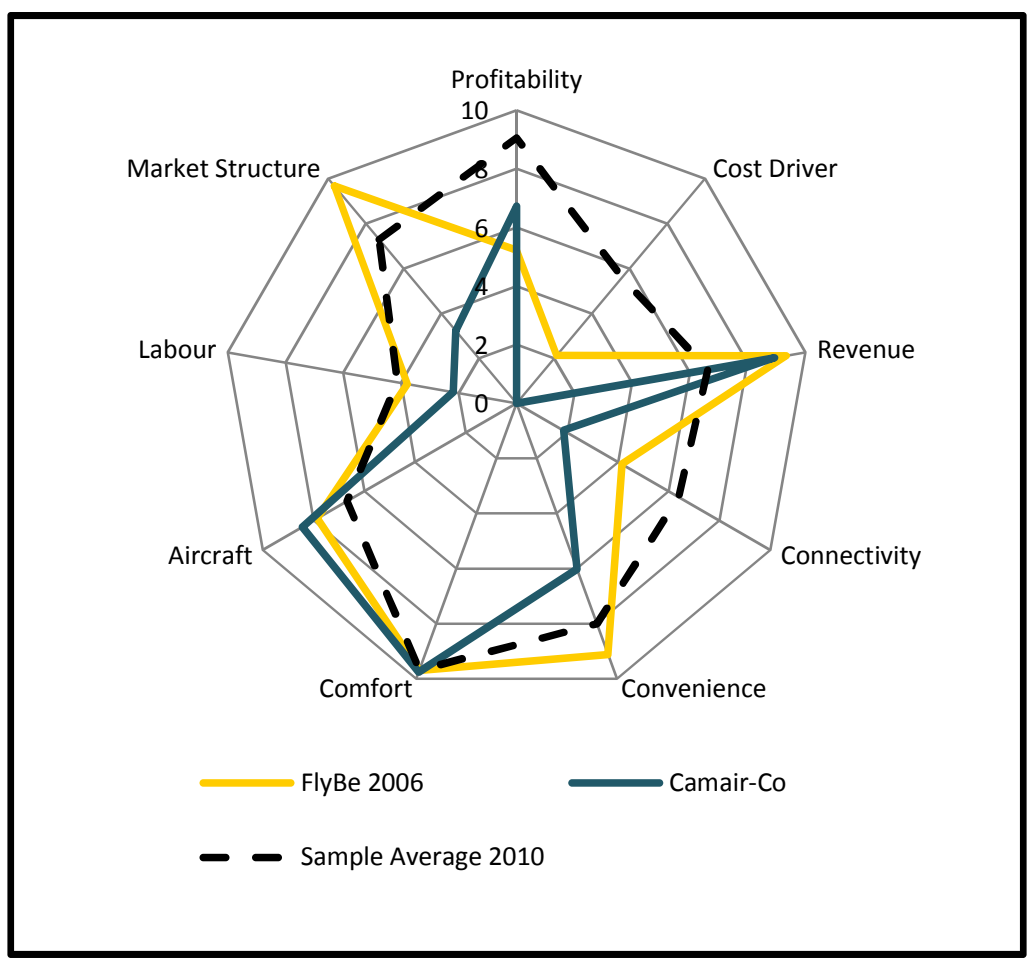

The LHNC effectively represents a "contracted" version of the FSNC, owing mainly to a poorer connectivity index. This is not surprising, given that this type of model is fundamentally based on niche point-to-point traffic. Air Mauritius has been used as the example in this case, and shows strong cost indices (Figure 9). This is expected because costs are amortised over longer distances and unit cost values are low. The carrier's labour index (productivity and cost) is poor, however, due to the lack of access to scale economies. A strong market structure index is in line with the notion

${ }^{5}$ Camair fleet comprises of just two 737-700s (128 seats including 12 in Business class) and a single 767 (210 seats including 30 in business class). 
that this model operates on long-haul niche markets which are often monopolies/duopolies.

Figure 9: Long Haul Nice Carriers (LHNC) results based on POA analysis

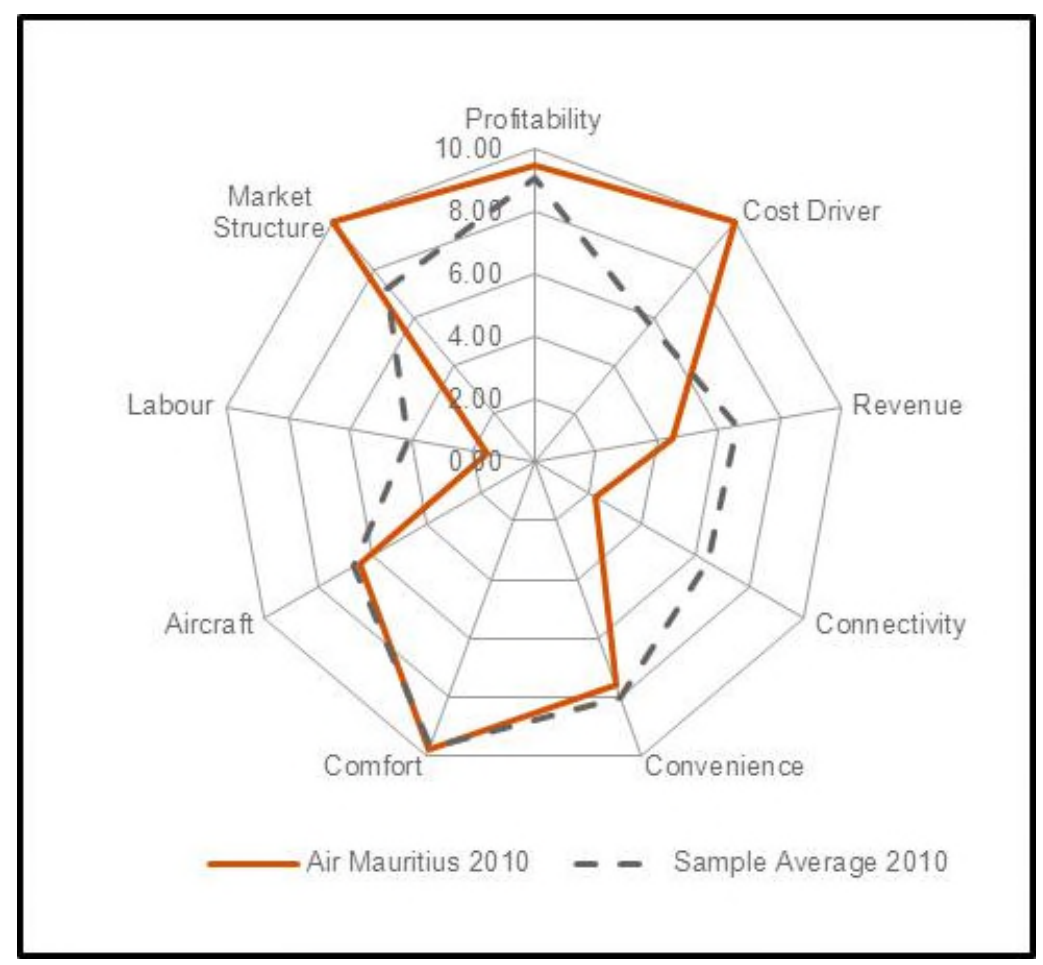

The existence of true low-cost carriers in Africa is limited almost exclusively to Northern and South Africa. 1Time airlines was selected here, being one of the only such carriers to publish sufficient data for use during the analysis, despite going bankrupt in late 2012. Nevertheless, as would be expected, the selected TLCC performed well in the labour, aircraft (utilisation) and cost indices (Figure 10) in relation to the rest of the sample. In 2010, 1Time's revenue position was similar to Ryanair's in 2006 (Ryanair's data is from M\&M's 2008 study) and when both carriers are compared, the South African LCC shows a markedly lower market concentration index. This is due to the carrier operating in the highly competitive South African domestic market, as opposed to targeting point-to-point markets in which the carrier might be the only operator. To some extent, the ruthless competitiveness of the South African domestic market compounded the airline's challenges of an old fleet and poor debt position. The challenge of strong competition is likely to face most African lowcost carriers as these carriers are most suited to dense domestic networks, which may also attract an abundance of other operators in the absence of the cost and regulation associated entry barriers that Ryanair typically benefits from in Europe. 
Figure 10: True Low Cost Carriers (TLCC) results based on POA analysis

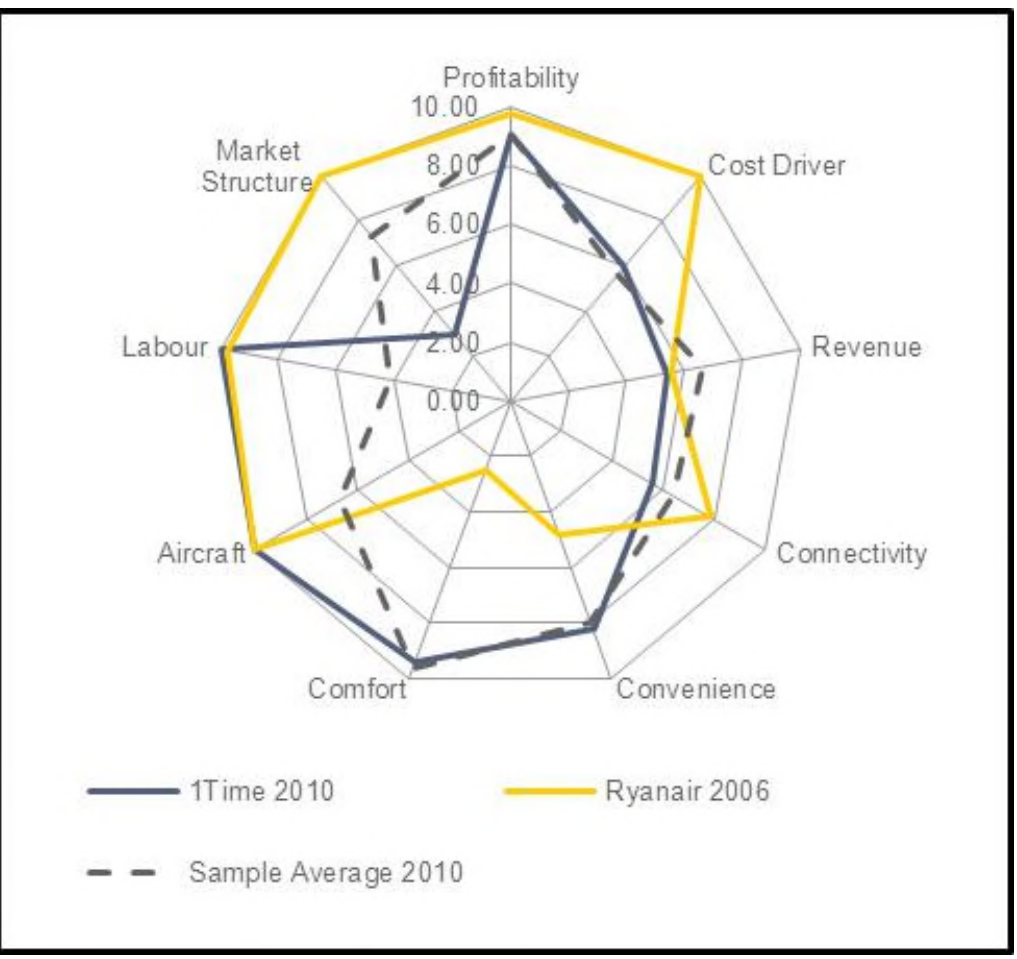

\subsubsection{Index correlation analysis}

While the POA analysis is useful in understanding the workings of individual models, its strength lies in its ability to be used to examine sustainable business models for Africa. A correlation analysis of each metric against every other metric was used to determine which model components are key to driving profitability. It shows two key relationships (Table 4):

Table 4: Correlation analysis

\begin{tabular}{|c|c|c|c|c|c|c|c|c|c|}
\hline & Profit & $\begin{array}{c}\text { Cost } \\
\text { Driver }\end{array}$ & Revenue & Connectivity & Convenience & Comfort & Aircraft & Labour & $\begin{array}{c}\text { Market } \\
\text { Structure }\end{array}$ \\
\hline Profitability & 1.00 & 0.08 & 0.20 & 0.63 & 0.58 & -0.33 & -0.48 & 0.02 & 0.43 \\
\hline Cost Driver & 0.08 & 1.00 & -0.93 & -0.21 & -0.27 & 0.06 & 0.01 & -0.15 & 0.31 \\
\hline Revenue & 0.20 & -0.93 & 1.00 & 0.30 & 0.32 & -0.16 & -0.23 & 0.01 & -0.15 \\
\hline Connectivity & 0.53 & -0.21 & 0.30 & 1.00 & 0.82 & 0.05 & -0.34 & 0.38 & 0.17 \\
\hline Convenience & 0.58 & -0.27 & 0.32 & 0.82 & 1.00 & 0.08 & -0.21 & 0.46 & 0.14 \\
\hline Comfort & -0.33 & 0.06 & -0.16 & 0.05 & 0.08 & 1.00 & -0.21 & -0.32 & 0.18 \\
\hline Aircraft & -0.48 & 0.01 & -0.23 & -0.34 & -0.21 & -0.21 & 1.00 & 0.49 & -0.83 \\
\hline Labour & 0.02 & -0.15 & 0.01 & 0.38 & 0.46 & -0.32 & 0.49 & 1.00 & -0.32 \\
\hline $\begin{array}{c}\text { Market } \\
\text { Structure }\end{array}$ & 0.43 & 0.31 & -0.23 & 0.17 & 0.14 & 0.18 & -0.83 & -0.32 & 1.00 \\
\hline
\end{tabular}


i. Connectivity and Profitability: An increase in connectivity can be accompanied by an increase in profitability. Taking into account metrics for each model for the year 2007 as well, then this relationship becomes obvious (Figure 11). It is more pronounced for the selected FSNCs in the POA sample, due to the fact these carriers are well positioned to profit from connectivity through their hubs. If high connectivity of passengers through hubs is combined with convenience, then profit should be driven upwards yet further, as demonstrated by the high and moderate convenience correlations with connectivity and profitability respectively.

Figure 11: Connectivity vs Profitability Correlation

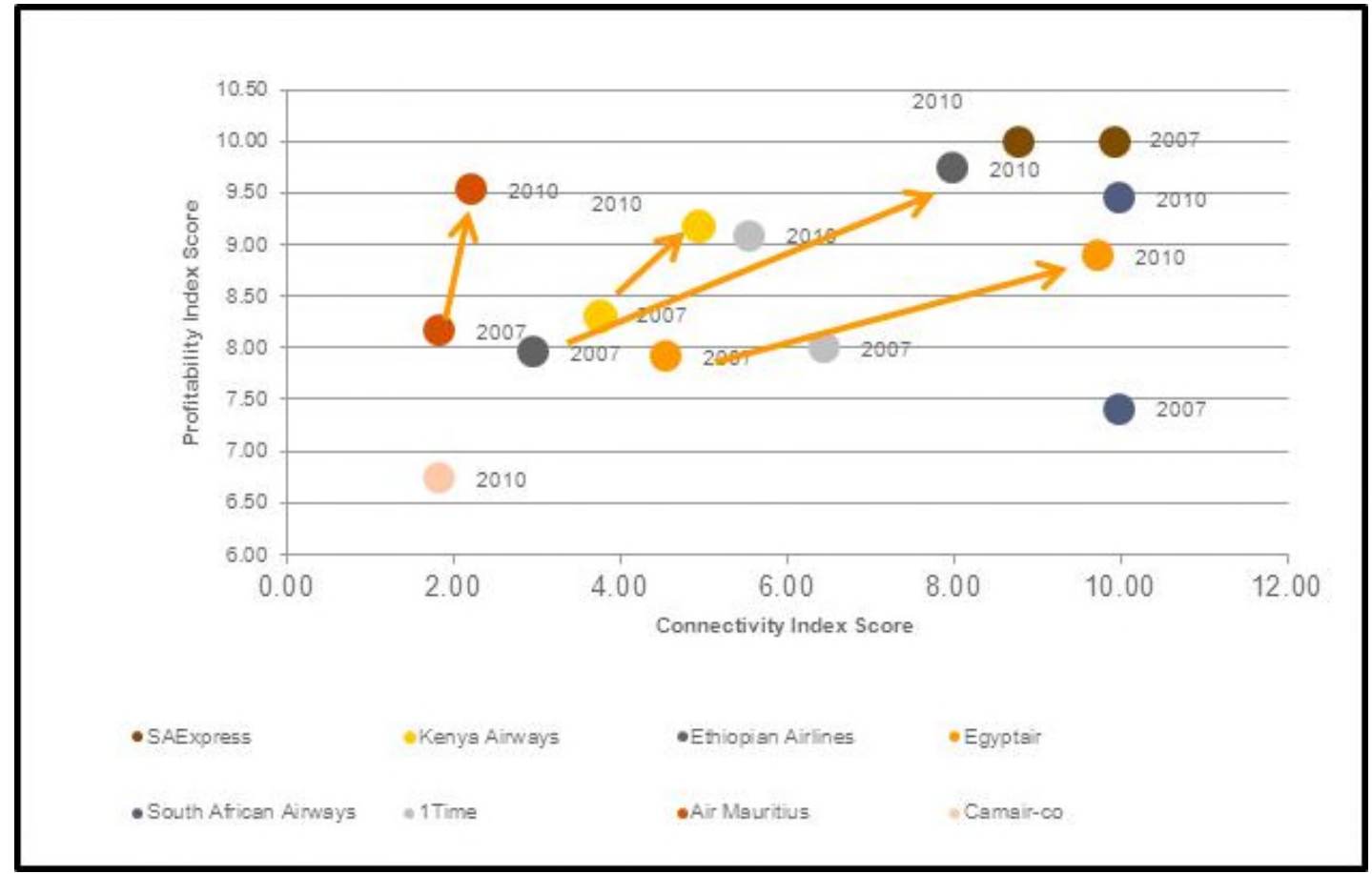

ii. Revenue and Cost leadership are mutually exclusive: No model performs well in both indices, and usually a strong performance in one index is accompanied by a weak performance in another index. In some cases, this may be reflective of strong intra-African yields resulting in a revenue focus, leaving cost performance somewhat neglected. In such cases, improving the cost position represents an opportunity to increase margins, but presents the risk of some yield erosion should such efficiencies lead to a real or perceived reduction in service.

By looking at both the connectivity score and an average of scores for all POA metrics combined, an idea of which models perform well in Africa and which can be considered sustainable, in terms of consistent profit delivery, can be observed. As shown by Table 5, the Established Regional Carrier (ERC) and Full Service Network Carrier (FSNC) models are prime candidates. Furthermore, considering the findings of the market analysis (Figure 5), which shows these models to be most applicable across different African markets, sufficient evidence is provided to support the contention that these models are likely to be the most sustainable in the African context. 
Table 5: Evaluation of model sustainability summary

\begin{tabular}{||c|c|c|c|c|c||}
\hline & $\begin{array}{c}\text { Full-service } \\
\text { network }\end{array}$ & $\begin{array}{c}\text { Established } \\
\text { regional }\end{array}$ & $\begin{array}{c}\text { Long-haul } \\
\text { niche }\end{array}$ & $\begin{array}{c}\text { True } \\
\text { low-cost }\end{array}$ & $\begin{array}{c}\text { Emerging } \\
\text { full-service } \\
\text { network }\end{array}$ \\
\hline $\begin{array}{c}\text { Connectivity } \\
\text { score }\end{array}$ & 8.16 & 8.79 & 2.23 & 5.59 & 1.86 \\
\hline Overall POA & 7.33 & 7.62 & 6.84 & 7.54 & 5.24 \\
\hline Sustainability & Good & Good & Moderate & Moderate & Weak \\
\hline
\end{tabular}

4.2.4 The recent development of Regional Feeders (ERCs) to Full Service Carriers (FSNC)

The analysis concluded that Established Regional Carrier (ERC) and Full Service Network Carrier (FSNC) models are prime candidates for sustainable profitability in Africa. In recent years there has been a growing collaboration between the two models in the form of joint ventures (e.g. code sharing, block space, etc), cross border and equity investments as witnessed by the partnerships between: Ethiopian Airlines and Togo's Asky Airlines together with Kenya Airways and Tanzania's Precision Air. These regional carriers were used as linchpins to redistribute traffic from the large network carriers and in turn feed traffic - in essence their primary function is 'to connect'. An insight into the partnership between Ethiopian and Asky reveals that the former took a $40 \%$ stake in the West African Togolese carrier which began operations in 2010, filling the gap left by the demise of African carriers such as Air Afrique, Nigeria Airways and Ghana Airways. Ethiopian has built much of its growth on developing its presence across the African market, and has supplemented its own base in East Africa by teaming with Togolese carrier Asky to give it a presence in West Africa. Despite having a fleet of only 4 aircraft, Asky's partnership with Ethiopian airlines, enhances the airlines hub feed at the Togolese base airport in Lomé. Such a model goes a long way to overcoming low load factors over sparse routes as well as adding additional revenue. PaxIS data reveals that Asky Airlines transported 95,000 passengers from 9 west African countries to Lomé airport in 2012 which provides a great potential source of feed to Ethiopian Airlines and vice versa. Fundamental to the success of this model is strong connectivity which is facilitated through schedule integration between the regional carrier and its partner. This is obvious at Asky's Lomé hub as shown in Figure 12 which displays a distinct midday hub bank providing the traffic feed to Ethiopian. 
Figure 12: Asky airlines hub bank at Lomé airport (2012 data)

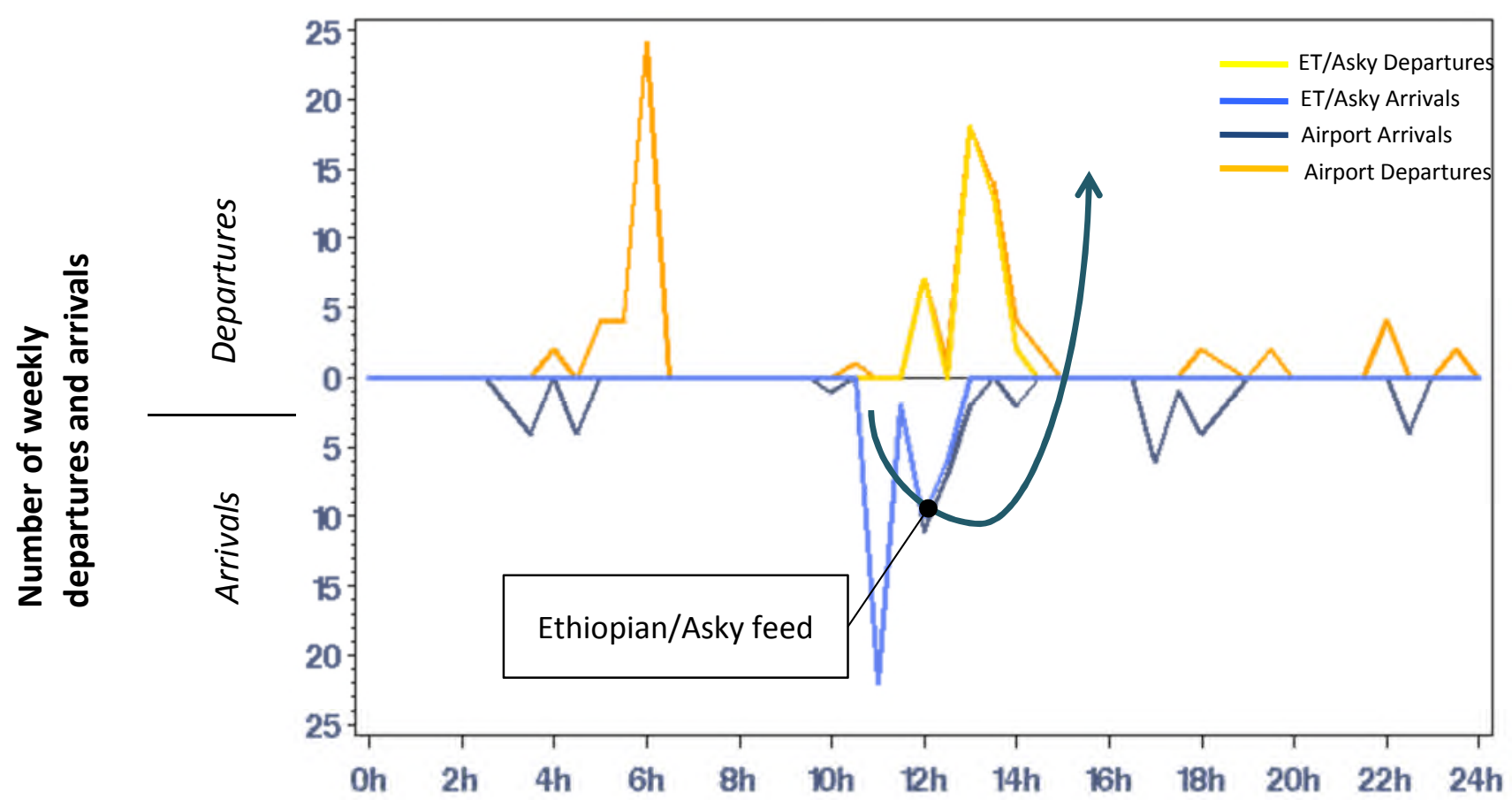

Time of Day

\section{Conclusion}

Using a stepwise Product and Organizational Architecture (POA) approach, this study aimed to determine the most financially sustainable business models for airlines based in African countries. It was hypothesized that the unique air transport landscape in Africa could warrant the creation of either a new business model or at least a renewed emphasis on the part of senior airline managers on the component parts of existing business models that drive forward financial sustainability more credibly.

In summary, it is clear that although Africa's chief air transport markets are not homogeneous, there are a number of continent-wide challenges which need to be considered when tailoring airline business models. Sparse demand over long sectors dictate that FSNC carriers which provide strong connections through centralised networks and make use of their scale, are likely to remain Africa's most sustainable business models. The financial success and ergo sustainability of these models, however, needs to be viewed in context with the government support they receive, financially or through stringent regulation. The latter was highlighted through the high HHI values of the markets in which these carriers operate, as seen in the cluster analysis. In a more localised sense, regional carriers are likely to remain central to the continent's air transport development, exploiting strong yields and enhancing 
connectivity through partnerships with larger FSNCs, particularly in smaller emerging markets. Increased collaboration between carriers, which also delivers a wide set of additional benefits such as the sharing of expertise, technical and operational support and additional revenues, goes a long way to enhancing connectivity which has been observed to be so fundamental to African airline business models in this study.

Taken together, the results appear to refute the idea of creating a completely new business model for African airlines. However, it is clear through the POA exercise that particular emphasis should be placed on ways of improving connectivity and pushing up average load factors, which have hitherto been comparatively sluggish in African markets. Existing full-service carriers with well-established international hubs, together with well-developed feeder networks either through regional partners or subsidiaries, proved to be the most sustainable in terms of year-on-year profit levels.

\section{References}

Abeyratne, R. 1998. The Future of African Civil Aviation. Journal of Air Transportation World Wide 3, 30-49.

Abrahams, 2002. Key Challenges facing air transport in Africa. 8th Aviation and Allied Business Leadership Conference, 1-2nd July. Johannesburg, South Africa.

Bieger, T., Döring, T. and Laesser, C. 2002. Transformation of business models in the airline industry, Salvador de Bahia: AIEST $52^{\text {nd }}$ Congress.

Buyck, C. 2010. Kenya Airways' Uplifting Mission. Booze Allen Hamilton.DLR, 2008. Topical Report: Airlines Business Models, Cologne: Deutsches Zentrum für Luft-und Raumfahrt.

Chingosho, E. 2009. African Airlines in the Era of Liberalisation, 2nd Ed, Nairobi.

DLR, 2008. Topical Report: Airlines Business Models. Cologne: Deutsches Zentrum für Luft- und Raumfahrt.

Doganis, R. 2012. Author interview (O'Connell) at Cranfield University, November $26^{\text {th }}$.

Doganis, R. 2010. Flying off course (4th ed.), Routledge, New York.

Dunn, G. 2012. Ethiopian sees encouraging progress on long-term goals, Flightglobal, 30 October, accessed at www.flightglobal.com.

Fageda, X. And Flores-Fillol, R. 2012. On the optimal distribution of traffic of network airlines. European Economic Review 56 (6), 1164-1179.

Gillen, D. 2006. Airline Business Models and Networks: Regulation, Competition and Evolution in Aviation Markets. Review of Network Economics 5, 366-384.

Gillen, D. and Gados, A. 2008. Airlines within airlines: assessing the vulnerabilities of mixing business models. Research in Transportation Economics 24, 25-35.

Gismatullin, E., 2011: .MPS. New Rules for Tapping Africa's Abundant Oil. Bloomberg Businessweek 4201, 18-19.

Global Market Information Database, 2013. Africa's mineral wealth, accessed through Cranfield University library database.

Graf, L. 2005. Incompatibilities of the low-cost and network carrier business models within the same airline grouping. Journal of Air Transport Management 11, 313327. 
Herszenhaut, M. 2010. Strategies of low cost airlines in emerging countries. Saarbrücken: Lambert Academic Publishing.

IATA, 2010. Air Transport Market Analysis. IATA.

ICAO, 2003. Background to Experiences of Liberalisation in Africa. International Civil Aviation Organisation.

Irandu, I. 2006. The Development of Jomo Kenyatta International Airport as a Regional Aviation Hub. Journal of Air Transport Management 11, 51-63.

Jarach, D., Miniero, G. and Zerbini, F. 2009. When legacy carriers converge with low-cost carriers: Exploring the fusion of European airline business models through a case-based analysis. Journal of Air Transport Management 15, 287293.

Kamara, D. 2012. Inaugural speech at ECOWAS transport conference, Mali

Mason, K. and Morrison, W. 2008. Towards a means of consistently comparing airline business models with an application to the 'low cost' airline sector. Research in Transportation Economics 24, 75-84.

Morrison, J.T. 2004. The current state of the airline industry in Southern Africa. Paper presented at the 23rd Annual Southern African Transport Conference 12-15 ${ }^{\text {th }}$ July 2004.

Niehaus, T., Ruehle, J. and Knigge, A. 2009. Relevance of route and network profitability analysis for the network management process of network carriers. Journal of Air Transport Management 15, 175-183.

O'Connell, J.F. and Warnock-Smith, D. (2012). Liberalization and strategic change in air transport: an examination of current and future variations in tourist traffic to and from Egypt resulting from policy changes at EgyptAir. Tourism Economics $18(4), 68-85$.

Ssamula, B. 2008. Strategies to design a cost-effective hub network for sparse air travel demand in Africa. PhD Thesis, University of Pretoria, South Africa.

Ssamula, B. 2009. Sustainable Business Models for the State-Owned African Airlines. Sustainable transport: 28th Annual Southern African Transport Conference (SATC) Southern African Transport Conference, Pretoria 6-9 ${ }^{\text {th }}$ July, 2009.

Ssamula, B. 2012. Comparing air transport network operations in sparse networks in Africa, Research in Transportation Business \& Management 4, 22-28.

Schlumberger, C. 2010. Open Skies for Africa: Implementing the Yamoussoukro Decision (Directions in Development: Infrastructure). Washington D.C: World Bank Publications.

Thomas, A. 2013. African Inroads, Airline Business 29, January, 38-40.

Tretheway, M. 2004. Distortions of airline revenues: why the network airline business model is broken. Journal of Air Transport Management 10, 3-14.

United Nations Economic Commission for Africa. 2001. Liberalisation of Air Transport Markets Access in Africa: The road forward for the implementation of the Yamoussoukro Decision, sub-regional meeting on the implementation of the Yamoussoukro Decision, 12-14 ${ }^{\text {th }}$ March 2001. 
2013-06-17

\section{Air transport in Africa: toward sustainable business models for African airlines}

Heinz, Stephan

Elsevier

Heinz, S. and O'Connell, J.F. 2013. Air transport in Africa: toward sustainable business models for African airlines. Journal of transport geography, 31, pages 72-83. DOI: 10.1016/j.jtrangeo.2013.05.004 https://dx.doi.org/10.1016/j.jtrangeo.2013.05.004

Downloaded from Cranfield Library Services E-Repository 